This item was submitted to Loughborough's Research Repository by the author.

Items in Figshare are protected by copyright, with all rights reserved, unless otherwise indicated.

\title{
State of Science: ergonomics and global issues
}

PLEASE CITE THE PUBLISHED VERSION

https://doi.org/10.1080/00140139.2017.1398845

PUBLISHER

(c) Taylor and Francis

VERSION

AM (Accepted Manuscript)

PUBLISHER STATEMENT

This work is made available according to the conditions of the Creative Commons Attribution-NonCommercialNoDerivatives 4.0 International (CC BY-NC-ND 4.0) licence. Full details of this licence are available at: https://creativecommons.org/licenses/by-nc-nd/4.0/

\section{LICENCE}

CC BY-NC-ND 4.0

\section{REPOSITORY RECORD}

Thatcher, Andrew, Patrick Waterson, Andrew Todd, and Neville Moray. 2019. "State of Science: Ergonomics and Global Issues". figshare. https://hdl.handle.net/2134/27862. 


\title{
State of Science: ergonomics and global issues
}

\author{
Andrew Thatcher \\ Department of Psychology, University of the Witwatersrand, South Africa \\ Andrew.Thatcher@wits.ac.za \\ Patrick Waterson \\ Design School, Loughborough University, United Kingdom \\ Andrew Todd \\ Department of Human Kinetics and Ergonomics, Rhodes University, South Africa \\ Neville Moray \\ Department of Psychology, University of Surrey, United Kingdom
}

\begin{abstract}
In his 1993 IEA keynote address Neville Moray urged the ergonomics discipline to face up to the global problems facing humanity and consider how ergonomics might help find some of the solutions. In this State of Science article we critically evaluate what the ergonomics discipline has achieved in the last two and a half decades to help create a secure future for humanity. Moray's challenges for ergonomics included deriving a value structure that moves us beyond a Westernised view of worker-organisation-technology fit, taking a multidisciplinary approach which engages with other social and biological sciences, considering the gross cross-cultural factors that determine how different societies function, paying more attention to mindful consumption, and embracing the complexity of our interconnected world. This article takes a sociohistorical approach by considering the factors that influence what has been achieved since Moray's keynote address. We conclude with our own set of predictions for the future and priorities for addressing the challenges that we are likely to face.
\end{abstract}

Keywords: global challenges; macroergonomics; green ergonomics; sustainable development; values

\section{Practitioners' summary}

We critically reflect on what has been achieved by the ergonomics profession in addressing the global challenges raised by Moray (1995). Apart from healthcare, the response has largely been weak and disorganised. We make suggestions for priority research and practice that is required to facilitate a sustainable future for humanity. 


\section{State of Science: ergonomics and global issues}

\section{Introduction}

At the $12^{\text {th }}$ Triennial Congress of the International Ergonomics Association (IEA) held in Toronto in August 1994, Professor Neville Moray gave a visionary, dystopian, keynote address laying out what he believed was the important role to be played by ergonomics in dealing with emerging global problems. This address was later published in Ergonomics (Moray, 1995). In his address, Moray drew inspiration from Wisner's (1985) understanding of the complexities of ergonomics in industrially developing countries (as they were called then) and Nickerson's (1992) views on emerging global environmental problems. Moray argued that ergonomics required a much broader systems definition incorporating issues such as cross-cultural considerations, an understanding of local contexts, global-environmental considerations, and multi-disciplinary solution-seeking. With a dark sense of foreboding, Moray suggested that the ergonomics challenges, based on economic and environmental instability, faced by industrially developing countries may very well prove to be the same challenges of industrially advanced countries in the decades ahead.

In this State of Science article we evaluate how far we have come in realising Moray's interpretation of the future and how the ergonomics discipline has gone about meeting his challenges. The structure of this article is as follows. We start by considering the historical context of Moray's article, the predictions that he made for the decades to follow, and the challenges that these posed for ergonomics. Next, we examine what work took place in the 1990s and 2000s that attempted to address the challenges raised by Moray. We then review the ergonomics work that has looked at Moray's seven global challenges and the general responses required by the ergonomics discipline. The article concludes with our own set of predictions and challenges for ergonomics in the future.

\section{The world in 1994 and Moray's (1995) challenges for the future}

In order to understand Moray's challenges for the future it is first necessary to set the scene. The year 1989 saw the collapse of the Soviet Union leading to a radical reorganisation of international treaties, the dismantling of massive nuclear weapon arsenals, and renewed efforts towards globalisation. Around this time, inclusive, democratic elections started taking place for the first time all over the world including in Africa, Eastern Europe, Latin America, Central Asia, the Middle East as well as reunification in Germany. Fukuyama (1992) declared, rather optimistically, that Western liberal democracy was the terminal point of humanity's ideological revolution and declared the "end of history". Globally, the average life expectancy at birth was 66.07 years, higher than it had ever been, and there were smaller proportions of people living in absolute poverty. The United Nations Development Programme (2010) noted that the world Human Development Index, a composite measure of national income per capita, life expectancy at birth, expected years of schooling, and mean years of schooling, had improved from 0.48 in 1970 to 0.57 in 1990 . In other, more technological, developments the World Wide Web became publicly available in 1993, spawning 
a wave of computer-supported innovations that provided new opportunities for commerce, communications, politics, entertainment, and research.

Not everything was perceived as positive, however. By 1994 the world's population had reached 5.6 billion people. As a point of reference, the world population only reached 1 billion in 1804 and 2 billion in 1927. This relatively recent rapid rise in population size has been attributed to a number of factors, but most significantly the industrial revolution that changed work production from organism-powered technology to technology powered by fossil fuels. On the positive side, the industrial revolution brought about enormous improvements in human wellbeing at work and improved living standards, and incredible advancements in medical science. However, on the negative side, by 1994 we had already started to see the impact that these vast numbers of people were having on the planet's life-sustaining ecosystems. Unfettered human consumption had led to several ecological crises including ozone depletion (Brasseur et al., 1990), acid rain (Galloway et al., 1984), and DDT abuse (Carson, 1962) that could each be attributed to anthropogenic causes.

Importantly, scientists were starting to see rises in global temperatures and were fairly confident that these could be attributed to the steady rise of greenhouse gases in the atmosphere (Hansen et al., 1988) brought about in particular by the burning of fossil fuels, although the scientific link between fossil fuels, greenhouse gases, and climate change was far from settled (Kerr, 1989) at that time. In response to the anticipated negative impacts on social and ecological systems due to these anticipated climate changes the Brundlandt Commission, formally known as the World Commission on Environment and Development, was created in 1987 followed by the Intergovernmental Panel on Climate Change (IPCC) in 1988. In another landmark development, 130 nations met in Rio de Janeiro in 1992 at the United Nations Conference on Environment and Development. At the Rio Earth Summit, as it has now known, these nations signed the Convention on Climate Change and reached agreement on a nonbinding action plan for climate change mitigation known as Agenda 21.

A number of other resources essential for human life were also under severe strain. Fresh water use was already being depleted at an incredible rate. According to Homer-Dixon (1993) approximately 3500 cubic kilometres of water were being used for human consumption annually world-wide, 1400 cubic kilometres was returned to ecosystems but usually in a severely degraded state, and 2100 cubic kilometres was being lost entirely. Food security was also becoming a problem through a combination of population increases and land degradation. Arable agricultural land was being reduced through human settlement, soil erosion was already high, and high quality land was becoming low quality land through nutrient depletion or overuse of chemical enhancers. Meyer and Turner (1992) estimated that between 5.44 and 20 million $\mathrm{km}^{2}$ of previously cultivated land had already been lost due to degradation. From an energy perspective, by 1994 there were already concerns about how existing energy sources would meet the energy demands of a burgeoning population and increasing per capita energy consumption (Holdren, 1991). The threats of waste and pollution were also ever-present. The near-disaster of Three Mile Island in 
1979 and the actual disaster at Chernobyl in 1986 had made it evident that nuclear energy might result in serious threats to human health and safety. The problems of air pollutants such as acid rain, ozone depletion, and urban air quality were already widely acknowledged, as were growing threats from oil spills such as the Ixtoc I in 1979 and Exxon Valdez in 1989, and other aspects of human consumption more generally (Hirschfeld et al., 1992). By 1994 approximately $44 \%$ of the world's population was living in urban settlements, up from 39\% in 1980 and 36\% in 1970. The problems of this rapid urbanisation were becoming evident including the failure of service delivery such as healthcare systems, the delivery of education, and transportation systems. Apart from wealthy inhabitants, urban environments often had poor access to recreational areas, long commutes to work (if they had a job), and high levels of violence (Cohen \& Swift, 1993). Humanity has a long history of terrorism and political violence. However, for much of humanity's history this has usually been fairly localised. In the decades leading up to 1994, political violence and terrorism had become more internationalised and extremely brutal.

It was in this context that Moray (1995) presented seven key global problems that he believed would challenge humanity into the twenty-first century and that could also be addressed through ergonomics applications. These challenges, their root causes, and the role of ergonomics are given in Table 1. Obviously these challenges are not independent, but complex and inter-related. For example, growing urbanisation places strain on energy, water, and food supply infrastructure, concentrates pollution and waste production, and can lead to increased violence. In contemporary literature this is sometimes referred to as the energy, water, climate, and food nexus (Dodds \& Bartram, 2016).

\section{[Table 1 about here]}

In looking at the future role of ergonomics Moray had a number of general suggestions. First, Moray argued that the ergonomics response should begin with a clear philosophy of values to guide solution-seeking for these emergent problems. In particular, there was a basic question of whether ergonomics should be primarily concerned with making workplaces tolerable and productive or facilitating a better quality of life in general. Moray favoured the latter interpretation of the role of ergonomics. Second, since these problems were highly complex and could not be resolved by ergonomics alone and therefore a multidisciplinary approach was required. Third, ergonomics solutions should entice and enforce appropriate behaviour change. In particular, solutions should focus on needs not on wants. Fourth, solutions should support cross-cultural diversity. Moray built on Wisner's (1985) notion of anthropotechnology, which adopts a broader systems approach requiring the incorporation of cross-cultural factors, geography, and cultural anthropology into our understanding of technology transfer. Since solutions need to acknowledge the ethics and morals of 'place', Moray argued that ergonomics needed to accept that few solutions are universal. 


\section{Ergonomics through the 1990s}

Wilson (2012) provided a summary of activities during the remainder of the 1990s. Apart from the continued emphasis on physical ergonomics (especially musculoskeletal disorders), the 1990s undeniably saw the maturation of cognitive ergonomics. Emerging from the Web boom, much of the ergonomics focus during the 1990s was on understanding the implications of work systems becoming information-intensive and distributed over geographical space. Terms such as joint cognitive systems, distributed cognition, situation awareness, mental workload, and virtual reality became common parlance. Similarly, due to increased computerisation in workplaces and the concomitant rise of complexity in organisations, Helander (1997) declared, in his IEA presidential address, the 1990 s as the decade of cognitive and organisational ergonomics.

In the wake of the collapse of the Soviet Union the 1990s saw a rapid internationalisation of work activities, often referred to as globalisation. This saw the geographical dispersion of work activities, usually involving the outsourcing of unskilled, dangerous, or manual labour to industrially developing countries. According to Wilson (2012) there was also a related emphasis on growing ergonomics in developing countries, although this appeared to be more of an outreach exercise than a true attempt to understand the challenges of these contexts. For example, in his keynote address at the IEA Congress in 2000, Shahnavaz (2000) looked at the issue of technology transfer to industrially developing countries and argued that it should take into account social, economic, and environmental needs. It is interesting that this was clearly a nod, without reference, to the triple bottom line understanding of sustainability (Elkington, 1998).

Noticeably absent from ergonomics research during the 1990s was empirical work that looked at the global challenges raised by Moray. The theoretical contributions that ergonomics could make to resolving global environmental and social challenges were raised again by Helander (1997) and Vicente (1998). Noticing that very little action had taken place since his 1995 article, Moray's (2000) keynote address at the San Diego IEA Congress again sought to draw attention to the need for a broader systems perspective in addressing ergonomics challenges. Some progress was being made in South America though. Garcia-Acosta (1996) introduced the term ergoecology when noting that there was a gap in the literature looking at the relationships between ergonomics and the environment. This work was published in Spanish and did not gain widespread attention apart from a small group of Spanish speakers who continued to promote this work at Congresses of Latin America in 1997 (and again in 1999). It is worthwhile to note that the theme of the Fourth Congress of Latin America in 1997 was "eco-ergonomia and quality of life". Interestingly, Charytonowicz (1998) also used the word "eco-ergonomics" to demonstrate that ergonomics should look at both human and environmental needs in the design of the built environment at the Organisational Design and Management Conference in the Netherlands. This work was published in a conference paper and also did not receive widespread attention. 


\section{The world in the twenty-first century}

In 2012 the world population passed 7 billion and will be more than 7.5 billion by the time this article is published. While year-on-year population growth is actually slowing, the World's population continues to increase dramatically in numerical terms and unless there is a significant intervention, it will likely be close to 10 billion by the middle of this century (see Figure 1). Frighteningly, scientists estimate that we are very close to reaching the theoretical carrying capacity (if we have not done so already) of the earth (Van den Bergh \& Rietveld, 2004).

[Figure 1 about here]

At the time of writing this article it is fair to say that many of Moray's original challenges still remain priorities for agencies, governments, and citizens around the world. Many of the challenges appear to have become even more relevant given recent political and societal developments. These include: the rise of nationalist movements in Europe and the US; terrorist networks operating across national and continental borders; the decision by the UK to leave the European Community following a referendum in June 2016 (the so-called 'Brexit'); and, neo-liberalist and protectionist developments in the US, underlined by the election of Donald Trump as President of the US in late 2016. These and other changes in the last twenty-years have provoked a number of debates centred on questioning many of the values and assumptions which are sometimes seen as having underpinned the twentieth century world. These range from scepticism considering the importance of capitalism as the driving force of economic prosperity such as the work of Thomas Piketty (2014) and Joseph Stiglitz (2015), scepticism about climate change, through to the dissemination of misinformation and an increase in unfettered threatening behaviour, partly brought about by the extensive and growing use of social media (Monbiot, 2016). It is no surprise then that given these circumstances many individuals feel a sense of confusion and bewilderment about the "posttruth' $^{1}$ nature of much of contemporary life.

Part of the reason why many people are anxious about these threats may be because of the ease with which information and misinformation can be accessed and shared. Marshall McLuhan $(1967,1968)$ writing in the 1960s predicted a future where widespread information provision had the potential to raise levels of anxiety amongst the general public. At the same time McLuhan argued that increased information sharing had the potential to bring about a 'global village' where individuals would feel a common sense of belonging and togetherness not tied to national borders or states. It is hard to assess the extent to which the 'global village' has been brought about half a century after McLuhan, but levels of anxiety, partly brought on by global and technological developments do seem to

\footnotetext{
${ }^{1}$ Defined as 'an adjective relating to circumstances in which objective facts are less influential in shaping public opinion than emotional appeals' (Oxford Dictionaries 2016 international word of the year - BBC, 2016 - 'Post-truth' declared word of the year by Oxford Dictionaries' http://www.bbc.co.uk/news/uk-37995600)
} 
be on the rise. Table 2 summarises some of the top ten global challenges as viewed from the perspective of one major non-profit foundation, the World Economic Forum, in 2016.

\section{[Table 2 about here]}

Aside from the list of global challenges listed in Table 2, a number of other topics dominate much of the debate surrounding the future in the first two decades of the twenty-first century. Many of these are centred on the role of automation and other technological developments such as 3D printing technologies, the Internet of Things, and the 'always on' ('24/7') society (Chen, 2011; Franklin, 2017). Other concerns raised by technology include threats caused by cyberattacks from individual criminals and other organised groups. The availability of large sources of 'big data' in what are sometimes seen as vulnerable repositories or data 'clouds', represent large-scale threats to cybersecurity for many countries and nations across the world. Advancements in technology have also seen significant changes to the way in which work is performed, the organisation of work systems, and the way labour protections operate, typically in high-income countries. New forms of work now include crowd work, on-demand work, and just-in-time work (de Stefano, 2015). However, globalisation and deregulation have also led to the emergence of less desirable work situations such as precarious work, informal work, outsourcing, and zero-hour contracts (Lavery, 2014). Finally, the impact of increasingly sophisticated forms of automation such as autonomous vehicles, intelligent robots, and neural implants raises many issues for ergonomics in the twenty-first century and beyond (Hancock, 2013; 2017). One of these issues is the future of employment and the extent to which advances in robotic technology will result in many jobs being automated. For example, latest estimates suggest that around $30 \%$ of jobs in the UK are at high risk of being lost to automation (PwC Consulting, March, 2017).

\section{Recent responses from the ergonomics community}

Since the early 2000s the response from the ergonomics community to Moray's global challenges has rapidly been growing, both from a theoretical perspective (e.g. Garcia-Acosta et al., 2012; Thatcher, 2013; Thatcher \& Yeow, 2016; Wilson, 2000; Zink, 2014) as well as through various practical interventions (e.g. Cocron et al., 2013; Fréjus \& Guibourdenche, 2012; Sauer et al., 2004). In critically reflecting on the response from the ergonomics community our review follows Moray's (1995) general suggestions. This review focuses on research publications that have appeared in the major ergonomics publications (especially Ergonomics, Applied Ergonomics, and Human Factors) and the main ergonomics conferences, as these are the sources that typically gain the most traction and influence. We acknowledge, given that we are looking at issues of a global nature, that there may also be important work that appears in other publications, including work in languages other than English. It is also possible, given the required complex multi- and interdisciplinary nature of work, that studies may have been reported in other disciplinary domains such as climate change, energy, health, food, and psychology where the individual contribution 
of the ergonomics profession is difficult to discern. These studies would also not appear in our review.

\subsection{Ergonomics values and quality of life}

Moray (1995) argued that the majority of published work reflects the "world of western liberal capitalism". Within this context, argues Moray, the role of ergonomics is clear; make workplaces safer and more productive. Moray asks whether ergonomics is "really nothing more than this?" (p. 1692). He noted that ergonomics needed a philosophy of values to guide our approaches to solving global problems. A response to this challenge was first attempted by Wilkin (2010). Wilkin (2010) noted that the dominant paradigm within the ergonomics discipline was one of ergonomics as a science, where it is argued that values are generally considered to fall outside of our domain. Wilkin (2010) noted that this 'value-free' ideology of ergonomics essentially supports the status quo values of work systems and therefore are not actually value-free. Hancock and Drury (2011) took this challenge further and noted that ergonomics research and practice is largely aimed at addressing the quality of life of the 'few' people who were the specified subject of investigations. In these cases the benefit is towards people funding the research or practice and the values are those of financial stability. Instead, Hancock and Drury (2011) challenged ergonomics to consider the broader question of how we might contribute to quality of life for all communities, societies, and indeed the human population. Building on Wilkin's (2010) work, Dekker et al. (2013) considered the values for ergonomics in the context of sustainability. For them, sustainability and ergonomics should be about complex system assessment (e.g. understanding how local interactions have global consequences; understanding interactions across time through lifecycle assessments) and emergence (i.e. anticipating the unforeseeable). While these are not values in themselves, Dekker et al. (2013; p. 362) noted that ergonomists "must not be afraid of nor shy away from a robust discussion on values" in the context of sustainability.

In a further extension, Lange-Morales et al. (2014) went on to develop a set of six values for ergonomics in the context of sustainability challenges. These values are:

- respect for human rights;

- respect for the Earth;

- appreciation of complexity;

- respect for diversity;

- respect for transparency and openness; and

- respect for ethical decision-making.

To date there has been very little acknowledgement of these values or any debate about their completeness, significance, or relevance in the published ergonomics literature. ErgoAfrica, the network of African Ergonomics societies, recently adopted these principles as their guiding values in the official bylaws of this network. These values are closely related to those articulated by both Moray (1995) and Wisner (1985) as they emphasise accepting that local and indigenous solutions often have precedence over solutions that attempt to enforce 'global' or 'Westernised' solutions. Another important set of values to consider are those of the recipients of ergonomics interventions. As is advocated within participatory 
approaches to ergonomics, the values of the recipients must also be considered if ergonomics interventions are to serve the needs of the recipients.

\subsection{Multidisciplinary approaches to resolving ergonomics problems}

Since ergonomics knowledge and practice emerges from a multitude of different disciplines a multidisciplinary approach should be a fairly straightforward exercise, especially as engineers, designers, and ergonomists frequently share disciplinary knowledge on many ergonomics projects. However, Moray's understanding of meeting global challenges went beyond looking at multidisciplinary communication between human sciences professions. Specifically, he suggested that ergonomics would need to look towards an integration of knowledge with the social sciences. There have been some responses in this regard. Wisner (1985) had already called for more engagement between ergonomics and anthropology and more recently Boudeau et al. (2014) called for greater engagement between ergonomics and politics. Manuaba (2007) reiterated the need for a systemic, holistic, interdisciplinary, and participatory approach to dealing with sustainability. For Manuaba (2007), the interdisciplinary requirements, a synthesis of knowledge and methods from different disciplines, for addressing the challenges posed by sustainability, require the integration of expertise from multiple different domains including ecologists, anthropologists, historians, social workers, engineers, ergonomists, and possibly even international relations expertise.

Despite these calls one could argue that very few ergonomics projects actually show the inclusion of multidisciplinary work. One example of the type of multidisciplinary work that is required to address Moray's global challenges is given in Moore and Barnard (2012). Their study, using what they called the Sustainable Livelihoods Framework, involved specialists from social anthropology, economics, planning, physical sciences, ergonomists, as well as the local community. The project goal was to ensure that local communities in the study area could develop sufficient social, natural, economic, and cultural capital to survive and even to thrive into the future (Moore \& Barnard, 2012).

Arguably, another way of looking at a multidisciplinary approach would be to consider the increasing number of studies that have adopted a participatory ergonomics approach (Haines et al. 2002). Participatory ergonomics requires recipients of ergonomics interventions to be active participants in the design and evaluation process, effectively making them subject-area experts. Lange-Morales et al. (2014) and Manuaba (2007) both suggested that participatory ergonomics approaches should be one of the preferred methods for addressing sustainability issues. We would argue that our future challenges require ergonomics to go further and to consider transdisciplinary approaches where disciplinary knowledge and methods are integrated to create new, unified theoretical frameworks not limited to specific disciplinary stances.

\subsection{Focusing on needs vs. wants}

Admittedly, very little work has taken place in the ergonomics field specifically examining the differences between needs and wants. In philosophical and social science contexts "needs" refer to basic human rights required for survival (e.g. 
water, air, food, etc.) whereas "wants" refer to all the other attributes that require satisfying (McGregor et al., 2009). Of course, it is not always that simple since there may be considerable debate over what is actually considered to be a basic human right. Furthermore, what is considered a "need" in one context (e.g. a safe work environment) might be considered a frivolous "want" in another context (e.g. where unemployment rates are high and actually having a job is the need). Most ergonomics work, while implying that the terms are different, actually considers needs and wants as synonymous in design considerations (see for example, Davidsson \& Alm, 2014). In trying to draw distinctions between the work required for sustainability and the work required in design for pleasure, Thatcher (2012) implied that the goals of these terms were different but did not explicitly evaluate the underlying philosophy of needs compared to wants. Rasmussen's (1997) dynamic safety space model doesn't explicitly mention needs and wants but these can be inferred from economic failure boundaries and unacceptable workload boundaries. For example, the desire to fulfil one's wants such as the economic success of a business, could be a reason for a migration towards a failure to meet the company's needs which might include unacceptable workload boundaries. In Jordan's (2000) hierarchy he specifically draws a distinction between functional 'needs' /usability and aspirational 'needs', which might be better framed as wants. Jordan argued that most ergonomics work focuses on needs and argued that more ergonomics work needs to focus on our aspirational wants, a direct contradiction to Moray.

\subsection{Cross-cultural diversity in ergonomics}

In this article we are not focused on the considerable amount of work done on the small-scale cross-cultural differences such as population stereotypes and perceptual preferences, although these are also important considerations. The importance of culture is emphasised by Hawkes (2001) who recommended that cultural capital be added to the triple bottom line to form a quadruple bottom line (Moore and Barnard (2012) applied this approach). We are most interested, as was Moray, in the larger issues of how culture is related to societal differences. The need for these types of cross-cultural diversity considerations predates Moray's keynote address. Wisner's (1985) work, in particular, stands out as a call to consider the requirements related to localised context. Moray (1995) commented that it was ironic that Wisner was honoured at the 1993 IEA Congress when "there is almost no evidence of any interest in Wisner's programme within the major professional ergonomics societies" (p. 1691). Moray also noted that special interest groups in technology transfer in major societies had actually collapsed. An important juncture in the history of ergonomics where significant change could have been implemented was in the influential future of ergonomics article by Dul et al. (2012). The Dul et al. (2012) article acknowledged that the committee commissioned to develop the document was comprised of mainly Western academics (as well as mostly men, older academics, and few practitioners). This is reflected in the article's content, with only cursory engagement with ergonomics requirements for emerging and under-developed countries. While they mentioned that global change in work systems was an important factor for the future of ergonomics with a shift of manufacturing capacity from "developed" countries to "developing" countries, they failed to indicate in any detail what this may actually mean for developing 
countries, their workforces, and the application of ergonomics within these countries. It is telling that the work of Wisner does not feature anywhere in the Dul et al. (2012) article, even considering that references were provided as "illustration and further reading" (p. 378). The important works of Moray (1995), Nickerson (1992), Scott (2008), Shahnavaz (2000), or Vicente (1998) were also not included to shape our understanding of the future of ergonomics.

Moray was also interested in whether ergonomics would look at ergonomics within informal economies, so prevalent in many developing countries. Dul et al. (2012) did acknowledge that in "some countries" (p. 380) the informal economy constitutes the largest workforce. However, they failed to indicate, in any meaningful way, how this could contribute to the future of ergonomics. If one considers that the world bank figures indicate that the informal economy constitutes more than $50 \%$ of non-agricultural employment in South, East and Southeast Asia, Sub-Saharan Africa, and Latin America (Benjamin et al., 2014), it would appear that the informal economy is important to many (if not most) countries. Additionally, in terms of gross domestic product the World Bank estimates that approximately one third of global GDP is from the informal economy, while in Africa this figure is as high as 50\% to $80 \%$ of GDP (Benjamin et al., 2014). Additionally, and vitally important in terms of the future of ergonomics in Africa, is that the informal economy and the world bank policy research working paper (Benjamin et al., 2014) approximates that $90 \%$ of the GDP for new jobs on the continent comes from the informal economy. This is unfortunate, as the region of greatest growth for the IEA over the last few decades has not been in the established societies but rather from industrially developing countries (such as Latin America). It is particularly interesting to note that these societies have been heavily influenced by the Francophone approach and the work of Wisner, specifically the use of activity analysis to understand the actual needs of the people.

A key consideration for a cross-cultural understanding could be made within the post-colonial context in many countries across the globe, but more specifically in Africa. A combination of colonial work practices and technology transfers have left a complex array of working environments that seldom take due consideration of indigenous systems or cultures. As an illustrative example, a traditional Southern African philosophy known as Ubuntu emphasises the importance of making decisions that are best for the collective. A cross-cultural understanding of how Ubuntu interacts with western cultures that typically characterise global work practices is sorely lacking. Such understanding, coupled with the broader theme of anthropotechnology in emerging markets, would add value to ergonomics in these countries, as emphasised by Wisner (1985).

\subsection{Empirical work addressing Moray's seven problems of the future through ergonomics}

Radjiyev et al. (2015) noted that the number of articles that referenced issues concerned with sustainable development had steadily increased since 2004, although the work has been concentrated on localised interventions such as product design and behavioural interactions with specific products rather than on more global, systemic problem-solving. While a significant number of articles 
have set out theoretical agendas for how the ergonomics discipline can contribute to these challenges (Drury, 2014; Hanson, 2013; Helander, 1997; Richardson et al., 2017; Thatcher, 2013; Vicente, 1998; Wilson, 2012), the actual number of empirical studies addressing these challenges is far smaller. A summary of Moray's challenges and examples of empirical work that fall broadly into these challenge areas is given in Table 3.

\subsubsection{Water issues}

There have been only a very small number of studies that have considered how ergonomics might contribute to alleviating water stress. These studies have looked at the design of simple products to reduce water wastage and include looking at interactions with public bathroom taps (Alli et al., 2013), a water management system in a green building (Kalantzis et al., 2016), the interface of a water-saving device (Fang \& Sun, 2016), and the design of a kettle (Sauer \& Rüttinger, 2004).

\subsubsection{Food issues}

No studies are known that have looked at how ergonomics can contribute to sustainable food production. There have been a number of studies that have looked at ergonomics issues in the agricultural, fishing, and food processing sectors such as musculoskeletal problems from fruit picking activities or the design of meat processing factories. However, these studies have only considered the health, wellbeing, and effectiveness of individual workers rather than the systemic impacts on producing more food more effectively.

\subsubsection{Energy issues}

The response from the ergonomics discipline through involvement in the design of safe and efficient energy systems has been comprehensive. This has included considerations in the design of household products (Kobus et al., 2013; Revell \& Stanton, 2016; Sauer et al., 2004; Sauer \& Rüttinger, 2004; Stedmon et al., 2013), design for energy efficient behaviours in a variety of systems (Cocron et al., 2013; Christina et al., 2014; Fréjus \& Guibourdenche, 2012; Stedmon et al., 2013), and design to support entire energy efficiency systems (Beltman et al., 2013; Hilliard \& Jamieson, 2011). There are still many places where ergonomics can continue to contribute, particularly in the design of various energyconsuming products and services, but especially in the areas of energy efficient behaviours and the design of entire energy generation systems such as smart grids.

\subsubsection{Urbanisation}

While there have been a number of theoretical pieces of work looking at the contributions of ergonomics towards designing urban environments (de Carvalho, 2012; Guimarães, 2012; Steffan, 2012; Wolf, 2003), the empirical work is scarce. Stanton et al. (2013) probably comes the closest to an "empirical" investigation with their cognitive work analysis exploring the constraints of moving commuters onto public transport systems, specifically rail. To date, the response from the ergonomics discipline on issues related to urbanisation has been disappointing and yet more than half of the world's population is urbanised (United Nations, Department of Economic and Social Affairs, Population Division, 
2015). Richardson et al. (2017), in particular, provide a number of suggestions related to the importance of human-nature connections, especially for urban contexts, that justify further investigation.

\subsubsection{Violence and terrorism}

In the aftermath of the $9 / 11$ terrorist attack there was a notable increase in the number of ergonomics jobs in military applications and articles making suggestions for how ergonomics might increase public safety through threatdetection equipment. Starting with a special issue of Ergonomics in Design (e.g. Hancock \& Hart, 2002) and continuing with numerous papers at HFES Annual Meetings (e.g. Fiore et al., 2003; Wise, 2002), this work was largely theoretical. Since the late 2000s the published work (e.g. Koller et al, 2009) has explored the design of a number of technological interventions that have primarily supported the design of detection technology such as x-ray scanning technology.

\subsubsection{Pollution and waste}

The ergonomics work on reducing waste and pollution falls into two categories; lean manufacturing that includes waste reduction and the design of recycling systems. One of the principle aims of lean manufacturing is to reduce wasteful use of resources, including wasteful use of human resources. Understandably, much of the work in the area of lean manufacturing (e.g. Cirjaliu, \& Draghici, 2016; Genaidy et al., 2009; Koukoulaki, 2014) has focused on the preservation of the human resource such as stress, musculoskeletal problems, and safety. Very little of the ergonomics literature has looked at how the human factor may assist in the reduction of waste from other sources such as workplace changes to reduce paper wastage or the inadvertent use of other limited resources. Hanson and Vangeel's (2014) work is one of the exceptions. They looked at various ergonomic workplace interventions in a chemical cleaning plant which resulted in the reduction in chemical by-products as well as a concomitant decrease in unnecessary work practices. The studies on recycling centres have looked at how the recycling task can be made easier, more efficient, and safer (e.g. Durugbo, 2013; Engkvist, 2010). The hope is that these developments would make recycling easier and therefore would increase recycling efforts.

\subsubsection{Health and medicine}

The response from the ergonomics discipline with regards to health and medicine has been extensive. Some of this work is exemplified in the book, edited by Carayon (2011), on healthcare ergonomics and patient safety. The work on healthcare has largely been concerned with the health and safety of healthcare professionals, patient safety (which was one of the intentions in Moray's original conceptualisation), and improvements in healthcare scenarios as sociotechnical systems. However, what is missing from the ergonomics discipline's response is the design of entire healthcare systems such as the equitable provision of healthcare between urban and rural settings or the effective and efficient provision of emergency services. Moore and Barnard (2012) partially address this latter context in one of their examples that considers the ergonomics issues of emergency service provision for disaster management. More of this type of work is required. 
[Table 3 about here]

\subsection{Emerging work emphasising complex systems}

The challenges identified by Moray are obviously not independent, but show a high degree of interdependence and complexity. The theoretical models that have recently been developed linking ergonomics and global challenges each emphasise the need to take a complex systems approach. Vicente (1998) made the observation that a complex systems understanding would be required to address Moray's global challenges. Since then, the theoretical models of human factors and sustainable development (Steimle and Zink, 2006; Zink and Fischer, 2013), green ergonomics (Hanson, 2010; Thatcher, 2013; Richardson et al, 2016), ergoecology (Garcia-Acosta et al, 2014), sustainable system-of-systems (Thatcher \& Yeow, 2016a; 2016b), supply chain ergonomics (Hasle \& Jensen, 2012), and lifecycle ergonomics (Zink, 2014) each emphasise the requirement of a complex systems understanding. Similarly, the values espoused by LangeMorales et al. (2014) also emphasise an appreciation of complexity as a core value.

Significant progress has been made in the ergonomics field on understanding and appreciating the need to consider complex systems (Dul et al., 2012; Hollnagel, 2014; Wilson, 2000; 2014) including sustainability and complexity (Dekker et al., 2013). However, the required extent of our detailed understanding of complex systems exceeds our current understanding in the discipline. Recently, Salmon et al. (2017) questioned whether ergonomics has the existing evaluation tools to deal with this level of complexity. The complexity that Moray invited ergonomics to address extends beyond human-technology interactions or human-organisation interactions. The "environment" is not merely the "context" in which human interactions take place. Our interactions are fundamentally changing our environment at a timescale that stretches across generations and spatial reach that extends around the whole planet. The complexity that requires our attention therefore stretches across extended periods of time, such as product lifecycle ergonomics (Zink, 2014) or the sustainable system-of-systems perspective (Thatcher \& Yeow, 2016a), as well as across extensive geographical space, such as supply chain ergonomics (Hasle \& Jensen, 2012).

\section{Discussion and a future agenda for ergonomics}

\subsection{Summary}

The future is not quite as pessimistic, at least not yet, for the majority of citizens of developed countries as Moray predicted, but this may still be a matter of timing. In fact, in some instances the reverse has happened with concerted efforts from certain developing countries (most notably China) leading to significant increases in living standards. Unfortunately, these developments have placed even more strain on limited resources such as food, water, and fossil-fuel energy sources and exacerbated some of the resource-dependent issues raised by Moray. What has happened though, is that the issues have become more interrelated and complex, requiring different approaches from the ergonomics discipline. There is a growing body of work that is trying to understand complex, dynamic, socio-technical systems (Guastello, 2017; Rasmussen, 1997; Salmon et 
al., 2017; Thatcher \& Yeow, 2016a; Walker et al., 2017; Wilson, 2014) from an ergonomics perspective, although not always with the intention of addressing Moray's challenges. In addition, new challenges have emerged. In particular, the challenges related to automation, robotics and the impact these developments might have on employment prospects have become prominent (Hancock, 2017). Based on the review of empirical work addressing Moray's seven problem areas it is evident that only the energy and health and medicine issues have been addressed with any degree of rigour over the last twenty-five years. Even the responses to these two problem areas have largely focused on the simple human-human and human-technology interaction systems. Very little work has been published that empirically examines the significant, complex, dynamic systems that underpin these problems. This is not to say that no work has been done, but rather that the response has been weak, largely theoretical, and uncoordinated. This may be because the challenges are perceived as overwhelming, that the ergonomics profession finds it difficult to work together with other professions, that the perceived funding opportunities in ergonomics do not support these types of investigations, or that the issues at stake are perceived to be beyond the competencies of the ergonomics discipline. However, since Moray (1995) an increasing number of authors have suggested that ergonomics can and should be part of the solution (Guimarães \& Soares, 2008; Hanson, 2013; Haslam \& Waterson, 2013; Nemire, 2014a; Thatcher, 2013; Thatcher \& Yeow, 2016a; Vincente, 1998; Wilson, 2000; Zink, 2014). The significant milestones on the road to meeting these challenges are summarised in Table 4.

\section{[Table 4 about here]}

It is also apparent that very little attention has been paid to the principles that Moray suggested should underpin the ergonomics response. These include the need to consider the values of the ergonomics discipline (only Lange-Morales et al. (2014) have made a concerted attempt), the issue of multidisciplinarity or even transdisciplinarity, whether ergonomics focuses on needs rather than wants, and the importance of cultural context.

\subsection{A note of future optimism - 'The world we made'}

Rather like the optimism of Fukuyama's (1992) predictions at the beginning of the 1990s, much of the pessimism of today's discussions and debates may ultimately turn out to be unfounded. Exact predictions about the future are almost always wrong, especially with regards to timing and details as acknowledged by Moray (1995). However, it is clear that some reliable future trends are discernible. One of the most imaginative attempts to identify global trends and think clearly about their implications over the next few decades, as well as offer some suggestions as to how they might be combated, and in some cases exploited, is offered by Porritt (2013). Porritt provides an account of the world in 2050, written through the eyes of an imaginary diarist (Alex McKay) born in the year 2000. Porritt uses the diary as a device to set out a set of ten themes and trends which are accompanied by a set of developments (e.g. new forms of organising and promoting sustainability), designed to improve global living in 2050 (Table 6). 
It is interesting to note that some of Porritt's (2013) predictions have already come true (e.g. wealth disparities between rich and poor, taxes on sugary foods and beverages, and coral reef destruction). The point that needs to be made though is that Porritt also projects a positive future. This is a future, as we have noted, where ergonomics can play a meaningful role. Some examples include the design of eco-cities, portable housing, technology-supported learning, voting systems, air traffic control systems, and design for the prevention of cybertechnology attacks. Porritt's optimism demonstrates that many things can be combatted with the right focus and commitment.

\subsection{Perceived barriers in the role of ergonomics in addressing global issues} As we have already mentioned, financial opportunities often drive the types of systems with which ergonomists become involved. This means that ergonomists are often only involved in projects where observable gains can be demonstrated over relatively time-constrained periods. Many of the types of global issues that Moray (1995) invited ergonomics to address do not share these qualities. As such, until relatively recently, funding for global issues has been limited for ergonomists. As should be obvious in this article, the funding situation is changing, especially for projects concerned with sustainability, the design of resilient systems, and climate change. What are considered to be the most important issues to address may be different in various geographical contexts. For example, food and water issues are particularly acute in drier regions of the world, while urbanisation and energy are more relevant for industrialised regions of the world. Climate variability may exacerbate these differences. While the global issues raised here are interconnected, the chosen areas of intervention may be selected based on perceived immediacy rather than an understanding of the complexity in the entire global system.

While systems theory and complexity have been included as important contextual aspects of many ergonomics training programmes around the world for a number of years now, it is rare for ergonomists to be trained in how to apply these concepts to systems larger than a single organisation. We would argue that the understanding required to address problems at the global level requires a decent understanding of local, regional, and international influences. In a welcome development, a limited number of University training programmes have started to consider how ergonomics applies to global problems. A further barrier exists within the global project teams themselves. It is doubtful whether project leaders of complex, multinational interventions and leaders with geopolitical influence understand the role that ergonomics could play in helping to find resolutions. This is not a problem that is unique to dealing with global issues (e.g. ergonomics interventions frequently have to be "sold" to key decisionmakers in many organisations), but will still require skilled ergonomics communicators to make the arguments for the value that ergonomics can add. Finally, there might be concerns that ergonomics is already thinly spread and that engaging with issues of such a broad scope is beyond the competencies of our discipline. While this might be a valid point for those practitioners and 
researchers interested in resolving certain specific, containable problems, we would argue that this limited view of ergonomics is problematic in the face of a potential existential crisis for humanity. No research has systematically examined the reasons for why ergonomists focus on certain types of projects. The possible barriers that we have identified in this section are therefore necessarily speculative. Further research is required to understand the specific reasons why ergonomists have been drawn away from addressing global issues.

\subsection{Ways forward for ergonomics and sustainability}

We argue strongly that ergonomics can and should be an integral part of finding solutions to the current global challenges. Lange-Morales et al. (2014) argue that our responses should be guided by a careful examination of the core values underpinning our discipline. This is work that Moray (1995), Wilkin (2010), Hancock and Drury (2011), and Dekker et al. (2013) have been calling on for the last two decades and on which Lange-Morales et al. (2014) have only recently made the first concerted attempt. This endeavour clearly needs more thought and debate. It is also evident that addressing global challenges is not an endeavour that can be achieved by ergonomics alone. Indeed, Moray's call for more multidisciplinary work still applies. In this article we argue that our discipline needs to go a step further in order to create transdisciplinary approaches that combine theory and practice from different disciplines. While it can be argued that ergonomics already takes a transdisciplinary approach that combines theory from a number of other inter-related disciplines (notably combining theory from physiology, anatomy, biomechanics, psychology, sociotechnical systems, and design theory), more work is needed to engage with the other social sciences (e.g. sociology, political science, anthropology, and philosophy) and biological sciences in particular. Thatcher and Yeow's (2016a) work is an example of this type of approach by combining ergonomics theory with ecological theory.

Ergonomics, as a discipline, still has an internal preoccupation with microergonomic work (theoretically, in published research, and in practice). This is not intended to be a critique of micro-ergonomics. In fact, we would argue that micro-ergonomics has already had a clear and important role to play in addressing the global challenges facing humanity. The significant numbers of studies on energy efficient systems (Christina et al., 2014; Cocron et al., 2013; Fréjus \& Guibourdenche, 2012; Katzeff et al., 2012; Kobus et al., 2013; Revell \& Stanton, 2016; Sauer et al., 2004; Stedmon et al., 2013) provide examples of the role that micro-ergonomics can play. In fact we would argue that even more of these types of micro-ergonomics work are still needed to improve efficiencies in water usage and waste reduction (or encouraging recycling), and for the design of decent jobs (Hanson, 2013) for a number of critical and emerging industries including sustainable agriculture, the installation of renewable energy systems, recycling, security screening, cybersecurity, and healthcare. However, we have reached a stage where global challenges cannot only be addressed through micro-interventions in the hope that the adoption rate of sustainable technologies and behaviours will eventually have a global reach through incremental growth. What is now required are systems ergonomics and macroergonomics approaches that are even greater in scale. In these approaches, the 
"external environment" is not just a context for the system of interest, but an integral part of the system requiring attention from the ergonomist. The idea of supply chain ergonomics from Zink (2014) or the sustainable system-of-systems approach from Thatcher and Yeow (2016a) are theoretical examples of the type of work that will be required. The empirical work of Moore and Barnard (2012) and Hilliard and Jamieson (2011) provide practical examples of these types of large, distributed systems. Based on Moray's challenges, significant work is needed to understand the ergonomics requirements in public transport systems, eco-cities, healthcare systems, organisational ecologies, cybersecurity systems, and food distribution systems among many others.

\section{References}

Alli, A., Maluleke, M., Bhana, S., Solomon, T., Klipp, Y., \& Thatcher, A. (2013). Sustainability and usability of public bathroom taps. Contemporary Ergonomics and Human Factors, pp. 329-336.

Beltman, S., Vosslamber, S.M., Molderink, A., \& Noordzij, M.L. (2016). Toward the design of an energy consumption feedback system. Ergonomics in Design, 24(3), 9-16.

Benjamin, N., Beegle, K., Recanatini, F., \& Santini, M. (2014). Informal Economy and the World Bank. Policy Research Working Paper 6888.

Boudeau, C., Wilkin, P., \& Dekker, S.W. (2014). Ergonomics as authoritarian or libertarian: learning from Colin Ward's politics of design. The Design Journal, 17(1), 91-114.

Brasseur, G.P., Granier, C., \& Walters, S. (1990). Future changes in stratospheric ozone and the role of heterogeneous chemistry. Nature, 348, 626-628.

Brown, C. (2007). Eco-ergonomics. In Proceedings of the New Zealand Ergonomics Society Conference, Waiheke Island, 7-9 November 2007.

Carayon, P. (2011). Handbook of human factors and ergonomics in health care and patient safety. Boca Raton, CRC Press.

Carson, R. (1962). Silent Spring. Boston, Houghton Mifflin Co. Charytonowicz, J. (1998). Ergonomics in architecture. In P. Vink, E.A.P. Konigsveld \& S. Dhondt (Eds.), Human Factors in Organizational Design \& Management VI. Oxford, Elsevier.

Chen, B.X. (2011), Always on: how the iPhone unlocked the anything-anytimeanywhere future and locked us in. Philadelphia: Da Capo Press.

Christina, S., Waterson, P., Dainty, A., \& Daniels, K. (2015). A socio-technical approach to improving retail energy efficiency behaviours. Applied Ergonomics, 47, 324-335.

Cirjaliu, B., \& Draghici, A. (2016). Ergonomic issues in lean manufacturing. Procedia-Social and Behavioral Sciences, 221, 105-110.

Cocron, P., Bühler, F., Franke, T., Neumann, I., Dielmann, B., \& Krems, J.F. (2013). Energy recapture through deceleration-regenerative braking in electric vehicles from a user perspective. Ergonomics, 56(8), 1203-1215.

Davidsson, S., \& Alm, H. (2014). Context adaptable driver information - or, what do whom need and want when?. Applied Ergonomics, 45(4), 994-1002.

de Carvalho, R.J.M. (2012). ERGOPOLIS: an ergonomics approach applied to a city. Work, 41(Supplement 1), 6071-6078.

Dekker, S.W., Hancock, P.A., \& Wilkin, P. (2013). Ergonomics and sustainability: towards an embrace of complexity and emergence. Ergonomics, 56(3), 357-364. 
De Stefano, V. (2015). The rise of the 'just-in-time workforce': on-demand work, crowd work and labour protection in the 'gig-economy'. Geneva: International Labour Organisation.

Dodds, F., \& Bartram, J. (Eds.). (2016). The water, food, energy and climate nexus: challenges and an agenda for action. New York: Routledge.

Drury, C.G. (2014). Can HF/E professionals contribute to global climate change solutions? Ergonomics in Design, 22(4), 30-33.

Dul, J., Bruder, R., Buckle, P., Carayon, P., Falzon, P., Marras, W.S., Wilson, J.R., \& van der Doelen, B. (2012). A strategy for human factors/ergonomics: developing the discipline and profession. Ergonomics, 55(4), 377-395.

Durugbo, C. (2013). Improving information recognition and performance of recycling chimneys. Ergonomics, 56(3), 409-421.

Elkington, J. (1998). Cannibals with forks: the Triple Bottom Line of 21st Century business. Oxford: Capstone.

Engkvist, I.L. (2010). Working conditions at recycling centres in Sweden physical and psychosocial work environment. Applied Ergonomics, 41(3), 347354.

Fang, Y.M., \& Sun, M.S. (2016). Applying eco-visualisations of different interface formats to evoke sustainable behaviours towards household water saving. Behaviour \& Information Technology, 35(9), 748-757.

Fiore, S.M., Jentsch, F., Bowers, C.A., \& Salas, E. (2003). Shared mental models at the intra-and inter-team level: applications to counter-terrorism and crisis response for homeland security. In Proceedings of the Human Factors and Ergonomics Society Annual Meeting, 47(3), 439-443. Sage Publications: Los Angeles, CA.

Franklin, E. (2017, Ed.), Megatech - technology in 2050. London: Economist Books.

Fréjus, M., \& Guibourdenche, J. (2012). Analysing domestic activity to reduce household energy consumption. Work, 41(Supplement 1), 539-548.

Fukuyama, F. (1992). The end of history or the last man. New York: Free Press. Galloway, J. N., Likens, G. E., \& Hawley, M. E. (1984). Acid precipitation: natural versus anthropogenic components. Science, 226(4676), 829-831.

García-Acosta, G., (1996). Modelos de explicación sistémica de la ergonomía [Models of systemic explanation of ergonomics] Unpublished Master's thesis. México, DF: Universidad Nacional Autónoma de México.

García-Acosta, G., Pinilla, M.H.S., Larrahondo, P.A.R., \& Morales, K.L. (2014).

Ergoecology: fundamentals of a new multidisciplinary field. Theoretical Issues in Ergonomics Science, 15(2), 111-133.

Genaidy, A.M., Sequeira, R., Rinder, M.M., \& A-Rehim, A.D. (2009). Determinants of business sustainability: an ergonomics perspective. Ergonomics, 52(3), 273301.

Guastello, S.J. (2017). Nonlinear dynamical systems for theory and research in ergonomics. Ergonomics, 60(2), 167-193.

Guimarães, L.D.M. (2012). Sustainability and cities: a proposal for implementation of a sustainable town. Work, 41(Supplement 1), 2160-2168. Guimarães, L.D.M., \& Soares, M.M. (2008). A future with less of a gap between rich and poor. Ergonomics, 51(1), 59-64.

Haines, H., Wilson, J.R., Vink, P., \& Koningsveld, A.E. (2002). Validating a framework for participatory ergonomics (the PEF). Ergonomics, 45(4), 309-327. 
Hancock, P.A. (2013). Automation: how much is too much? Ergonomics 57(3), 449-454.

Hancock, P.A. (2017). Imposing limits on autonomous systems. Ergonomics, 60(2), 284-291.

Hancock, P.A., \& Drury, C.G. (2011). Does human factors/ergonomics contribute to the quality of life? Theoretical Issues in Ergonomics Science, 12(5), 416-426.

Hancock, P.A., \& Hart, S.G. (2002). Defeating terrorism: what can human factors/ergonomics offer? Ergonomics in Design, 10(1), 6-16.

Hansen, J., Fung, I., Lacis, A., Rind, D., Lebedeff, S., Ruedy, R., Russell, G., \& Stone, P. (1988). Global climate changes as forecast by Goddard Institute for Space Studies three-dimensional model. Journal of Geophysical Research: Atmospheres, 93(D8), 9341-9364.

Hanson, M. (2010). Green ergonomics: embracing the challenges of climate change. The Ergonomist, 480, 12-13.

Hanson, M.A. (2013). Green ergonomics: challenges and opportunities. Ergonomics, 56(3), 399-408.

Hanson, M., \& Vangeel, M. (2014). Chemical cleaning re-invented: clean, lean and green. Work, 49(3), 411-416.

Haslam, R., \& Waterson, P. (2013). Ergonomics and sustainability. Ergonomics, 56(3), 343-347.

Hasle, P., \& Jensen, P.L. (2012). Ergonomics and sustainability-challenges from global supply chains. Work, 41(Supplement 1), 3906-3913.

Hedge, A. (2008). The sprouting of 'green' ergonomics. HFES Bulletin, 51(12), 13.

Hawkes, J. (2001). The fourth pillar of sustainability. Cultures and local development. Melbourne: Cultural Development Network.

Helander, M.G. (1997). Forty years of IEA: some reflections on the evolution of ergonomics. Ergonomics, 40(10), 952-961.

Hilliard, A., \& Jamieson, G.A. (2011). Energy management in large enterprises: a field study. In Proceedings of the Human Factors and Ergonomics Society Annual Meeting, 55(1), 399-403). SAGE Publications: Los Angeles, CA.

Hilliard, A., Tran, F.F., \& Jamieson, G.A. (2016). A graphic form with emergent properties for monitoring renewable generation stations. In Resilience Week (RWS), August 2016, 162-165. IEEE.

Hirshfeld, S., Vesilind, P.A., \& Pas, E.I. (1992). Assessing the true cost of landfills. Waste Management \& Research, 10(6), 471-484.

Holdren, J.P. (1991). Population and the energy problem. Population and Environment, 12(3), 231-255.

Hollnagel, E. (2014). Human factors/ergonomics as a systems discipline? "The human use of human beings" revisited. Applied Ergonomics, 45(1), 40-44. Homer-Dixon, T. F. (1993). Environmental scarcity and global security. Headline Series No. 300. Foreign Policy Association, New York.

Jordan, P. W. (2000) Designing pleasurable products: an introduction to the new human factors, Taylor \& Francis, London.

Kalantzis, A., Thatcher, A., \& Sheridan, C. (2016). Mental models of a water management system in a green building. Applied Ergonomics, 57, 36-47. Katzeff, C., Nyblom, Å., Tunheden, S., \& Torstensson, C. (2012). User-centred design and evaluation of EnergyCoach-an interactive energy service for households. Behaviour \& Information Technology, 31(3), 305-324. 
Kerr, R. A. (1989). Hansen vs. the World on the greenhouse threat. Science, 244(4908), 1041-1043.

Kobus, C.B., Mugge, R., \& Schoormans, J.P. (2013). Washing when the sun is shining! How users interact with a household energy management system. Ergonomics, 56(3), 451-462.

Koller, S.M., Drury, C.G., \& Schwaninger, A. (2009). Change of search time and non-search time in X-ray baggage screening due to training. Ergonomics, 52(6), 644-656.

Koukoulaki, T. (2014). The impact of lean production on musculoskeletal and psychosocial risks: An examination of sociotechnical trends over 20 years. Applied Ergonomics, 45(2), 198-212.

Lange-Morales, K., Thatcher, A., \& García-Acosta, G. (2014). Towards a sustainable world through human factors and ergonomics: it is all about values. Ergonomics, 57(11), 1603-1615.

Lavery, S. (2014). The politics of precarious employment in Europe: zero hour contracts and the commodification of work. Precarious Employment in Europe. FEPS Young Economics Network Working Paper, Brussels, pp. 6-16.

Magliocca, N.R., Van Vliet, J., Brown, C., Evans, T.P., Houet, T., Messerli, P., \& Schweizer, V. (2015). From meta-studies to modeling: using synthesis knowledge to build broadly applicable process-based land change models. Environmental Modelling \& Software, 72, 10-20.

Manuaba, A. (2007). A total approach in ergonomics is a must to attain humane, competitive and sustainable work systems and products. Journal of Human Ergology, 36(2), 23-30.

Mayhorn, C.B., Wogalter, M.S., \& Bell, J.L. (2004). Homeland security safety symbols: are we ready?. Ergonomics in Design, 12(4), 6-11.

McGregor, J.A., Camfield, L., \& Woodcock, A. (2009). Needs, wants and goals: wellbeing, quality of life and public policy. Applied Research in Quality of Life, 4(2), 135-154.

McLuhan, M. (1967), The medium is the message: an inventory of effects. New York: Random House

McLuhan, M. (1968), War and peace in the global village. New York: Bantam Books.

Meister, D. (1999). The history of human factors and ergonomics. Mahwah, NJ: Lawrence Erlbaum Associates.

Meyer, W.B., \& Turner, B.L. (1992). Human population growth and global landuse/cover change. Annual Review of Ecology and Systematics, 23, 39-61.

Monbiot, G. (2016), The misinformation machine. The Guardian, November 30th. Retrieved from http://www.monbiot.com/2016/12/01/the-misinformationmachine/ (last accessed 22nd March, 2017).

Moore, D., \& Barnard, T. (2012). With eloquence and humanity? Human factors/ergonomics in sustainable human development. Human Factors, 54(6), 940-951.

Moray, N. (1995). Ergonomics and the global problems of the twenty-first century. Ergonomics, 38(8), 1691-1707.

Moray, N. (2000). Culture, politics and ergonomics. Ergonomics, 43(7), 858-868. Moray, N. (2008). The good, the bad, and the future: on the archaeology of ergonomics. Human, 50(3), 411-417. 
Nemire, K. (2014a). Combating climate change: the role of human factors/ergonomics, Part 1 - Special Issue. Ergonomics in Design, 22(2), 3-3. Nemire, K. (2014b). Introduction to the Special Issue on combating climate change: the role of human factors/ergonomics, Part 2. Ergonomics in Design, 22(4), 3-3.

Nickerson, R.S. (1992, October). What does human factors research have to do with environmental management? In Proceedings of the Human Factors and Ergonomics Society Annual Meeting, 36(9), 636-639.

Nickerson, R.S. (2011). Roles of human factors and ergonomics in meeting the challenge of terrorism. American Psychologist, 66(6), 555.

Nickerson, R.S., \& Moray, N. (1995). Environmental change. In R.S. Nickerson (Ed.), Emerging needs and opportunities for human factors research (pp. 158176). National Academy Press, Washington, DC.

Piketty, T. (2014) Capital in the Twenty-First Century. Cambridge, MA: Belknap Press.

Porritt, J. (2013). The world we made: Alex McKay's story from 2050. New York: Phaidon.

PwC (PricewaterhouseCoopers, 2017). Up to 30\% of existing UK jobs could be impacted by automation by early 2030s, but this should be offset by job gains elsewhere in economy. Retrieved from

http://pwc.blogs.com/press_room/2017/03/up-to-30-of-existing-uk-jobscould-be-impacted-by-automation-by-early-2030s-but-this-should-be-offse.html (last accessed 24th March, 2017).

Radjiyev, A., Qiu, H., Xiong, S., \& Nam, K. (2015). Ergonomics and sustainable development in the past two decades (1992-2011): research trends and how ergonomics can contribute to sustainable development. Applied Ergonomics, 46, 67-75.

Rasmussen, J. (1997). Risk management in a dynamic society: a modelling problem. Safety Science, 27(2), 183-213.

Revell, K.M., \& Stanton, N.A. (2016). Mind the gap - deriving a compatible user mental model of the home heating system to encourage sustainable behaviour. Applied Ergonomics, 57, 48-61.

Richardson, M., Maspero, M., Golightly, D., Sheffield, D., Staples, V., \& Lumber, R. (2017). Nature: a new paradigm for well-being and ergonomics. Ergonomics, 60(2), 292-305.

Saikayasit, R., Stedmon, A.W., \& Lawson, G. (2013). User requirements elicitation in security and counter-terrorism: a human factors approach. Journal of Police and Criminal Psychology, 28(2), 162-170.

Salmon, P.M., Walker, G.H., Read, G.J.M., Goode, N., \& Stanton, N.A. (2017). Fitting methods to paradigms: are ergonomics methods fit for systems thinking?

Ergonomics, 60(2), 194-205.

Sauer, J., \& Rüttinger, B. (2004). Environmental conservation in the domestic domain: the influence of technical design features and person-based factors. Ergonomics, 47(10), 1053-1072.

Sauer, J., Wiese, B.S., \& Rüttinger, B. (2004). Ecological performance of electrical consumer products: the influence of automation and information-based measures. Applied Ergonomics, 35(1), 37-47.

Scott, P.A. (2008). Global inequality, and the challenge for ergonomics to take a more dynamic role to redress the situation. Applied Ergonomics, 39(4), 495-499. 
Scott, P.A. (Ed.), (2009). Ergonomics in developing regions: needs and applications. Boca Raton, FL: CRC Press.

Shahnavaz, H. (2000). Role of ergonomics in the transfer of technology to industrially developing countries. Ergonomics, 43(7), 903-907.

Stanton, N.A., McIlroy, R.C., Harvey, C., Blainey, S., Hickford, A., Preston, J.M., \& Ryan, B. (2013). Following the cognitive work analysis train of thought: exploring the constraints of modal shift to rail transport. Ergonomics, 56(3), 522-540.

Stiglitz, J.E. (2015). The great divide: unequal societies and what we can do about them. New York: W.W. Norton \& Company.

Stedmon, A.W., Winslow, R., \& Langley, A. (2013). Micro-generation schemes: user behaviours and attitudes towards energy consumption. Ergonomics, 56(3), 440-450.

Steffan, I. (2012). Sustainability and accessibility: the Design for All approach. Work, 41(Supplement 1), 3888-3891.

Steimle, U., \& Zink, K.J. (2006). Sustainable development and human factors. International encyclopedia of ergonomics and human factors, 2258-2263.

Thatcher, A. (2012). Affect in designing for sustainability in human factors and ergonomics. International Journal of Human Factors and Ergonomics, 1(2), 127147.

Thatcher, A. (2013). Green ergonomics: definition and scope. Ergonomics, 56(3), 389-398.

Thatcher, A., \& Groves, A. (2008, September). Ecological ergonomics: designing products to encourage pro-environmental behaviour. In Proceedings of CybErg 2008: The Fifth International Cyberspace Conference on Ergonomics [CD-Rom]. Thatcher, A., \& Yeow, P.H. (2016a). A sustainable system of systems approach: a new HFE paradigm. Ergonomics, 59(2), 167-178.

Thatcher, A., \& Yeow, P.H. (2016b). Human factors for a sustainable future. Applied Ergonomics, 57, 94-104.

United Nations, Department of Economic and Social Affairs, Population Division (2015). World urbanization prospects: the 2014 Revision, (ST/ESA/SER.A/366). Van den Bergh, J.C.J.M. \& Rietveld, P. (2004). Reconsidering the limits to world population: meta-analysis and meta-prediction. BioScience, 54(3), 195-204. Vicente, K.J. (1998). Human factors and global problems: a systems approach. Systems Engineering, 1(1), 57-69.

Walker, G.H., Salmon, P.M., Bedinger, M., \& Stanton, N.A. (2017). Quantum ergonomics: shifting the paradigm of the systems agenda. Ergonomics, 60(2), 157-166.

Wilkin, P. (2010). The ideology of ergonomics. Theoretical Issues in Ergonomics Science, 11(3), 230-244.

Wilson, J.R. (2000). Fundamentals of ergonomics in theory and practice. Applied Ergonomics, 31(6), 557-567.

Wilson, J.R. (2012). Recurring issues in the IEA, the discipline and the profession of ergonomics/human factors. Work, 41(Supplement 1), 5041-5044.

Wilson, J.R. (2014). Fundamentals of systems ergonomics/human factors. Applied Ergonomics, 45(1), 5-13.

Wise, J.A. (2002). De-opportunizing design and its lessons for building security and counterterrorism. In Proceedings of the Human Factors and Ergonomics Society Annual Meeting, 46(9), 860-864. Sage Publications: Los Angeles, CA. 
Wisner, A. (1985). Ergonomics in industrially developing countries. Ergonomics, 28(8), 1213-1224.

Wolf, K.L. (2003). Ergonomics of the city: green infrastructure and social benefits. In C. Kollin (Ed.), Engineering Green: Proceedings of the 11th National Urban Forest Conference. Washington D.C.: American Forests.

World Economic Forum (2016). What are the 10 biggest global challenges?

Retrieved from https://www.weforum.org/agenda/2016/01/what-are-the-10biggest-global-challenges/ (last accessed 15th May, 2017).

Zink, K.J. (2014). Designing sustainable work systems: the need for a systems approach. Applied Ergonomics, 45(1), 126-132.

Zink, K.J., \& Fischer, K. (2013). Do we need sustainability as a new approach in human factors and ergonomics? Ergonomics, 56(3), 348-356. 
Table 1. Moray's seven problems of the future and role of ergonomics

\begin{tabular}{lll}
\hline \multicolumn{1}{c}{ Challenges } & \multicolumn{1}{c}{ Root causes in 1994 } & \multicolumn{1}{c}{ Role of ergonomics } \\
\hline Water scarcity & $\begin{array}{l}\text { Aquifer depletion; Uneven distribution } \\
\text { of fresh water }\end{array}$ & $\begin{array}{l}\text { Design of water conservation } \\
\text { systems and behaviour }\end{array}$ \\
\hline Food shortages & $\begin{array}{l}\text { Overuse of arable land; Overuse of } \\
\text { nitrogen as fertilizer; Intensive farming } \\
\text { practices }\end{array}$ & $\begin{array}{l}\text { Reducing consumption } \\
\text { behaviour; Increasing food } \\
\text { productivity }\end{array}$ \\
\hline Energy supply & $\begin{array}{l}\text { Growing urban population requiring } \\
\text { infrastructure, transportation, and } \\
\text { consumer goods (all require energy) }\end{array}$ & $\begin{array}{l}\text { Designing efficient and safe } \\
\text { energy industries }\end{array}$ \\
\hline Pollution \& waste & $\begin{array}{l}\text { Nuclear waste; Chemical waste; Plastic } \\
\text { accumulation; Oil spills; Chemical }\end{array}$ & $\begin{array}{l}\text { Design systems that don't } \\
\text { pollute; Design systems that } \\
\text { encourage recycling }\end{array}$ \\
& Lubricant spills; Carbon dioxide & $\begin{array}{l}\text { Design of megalopolies } \\
\text { Urbanisation }\end{array}$ \\
$\begin{array}{l}\text { Stress on transport systems and services } \\
\text { (e.g. sewerage); Decreased air quality; } \\
\text { Decrease in quality of life }\end{array}$ & $\begin{array}{l}\text { Design and operation of } \\
\text { security systems }\end{array}$ \\
\hline Violence \& & $\begin{array}{l}\text { Overcrowding; Poverty; Drought and } \\
\text { famine; Forced migration }\end{array}$ & $\begin{array}{l}\text { Design of efficient and safe } \\
\text { healthcare systems }\end{array}$ \\
\hline Herrorism & High cost of healthcare & \\
\hline
\end{tabular}


Table 2: ‘Top ten' global challenges in 2016 (World Economic Forum, 2016)

\begin{tabular}{|c|c|}
\hline Threat & Details \\
\hline 1. Food security & By 2050 there will be 9 billion people but demand for food will be $60 \%$ greater due to increased demand for living standards. \\
\hline 2. Wealth inequality & $\begin{array}{l}\text { Substantial increases in wealth for large numbers of people around the World in recent decades. However, existing social, } \\
\text { political, and economic systems continue to exacerbate wealth inequalities. }\end{array}$ \\
\hline 3. Unemployment & $\begin{array}{l}\text { More than } 61 \text { million jobs lost since global financial crisis in 2008. Currently more than } 200 \text { million potentially economically } \\
\text { active people unemployed worldwide. }\end{array}$ \\
\hline 4. Climate change & $\begin{array}{l}\text { Nearly a } 1^{\circ} \mathrm{C} \text { increase in average land temperature in past } 50 \text { years. This is largely attributable to greenhouse gas emissions } \\
\text { from the burning of fossil fuels. Temperature rise must be kept below } 2^{\circ} \mathrm{C} \text { to prevent major positive feedback loops from } \\
\text { happening. }\end{array}$ \\
\hline 5. Global finance & $\begin{array}{l}\text { Global financial systems are not resilient to acute shocks. Economic systems are still struggling with slow economic growth, } \\
\text { constrained government spending abilities, and confused monetary policies. }\end{array}$ \\
\hline 6. Internet connectivity & $\begin{array}{l}\text { Mobile and Internet technologies are changing existing models of commerce, governance, living, and consumption. This has } \\
\text { the potential to facilitate eco-efficiencies but there are challenges associated with data security, personal privacy, and the } \\
\text { maintenance of personal relationships. }\end{array}$ \\
\hline 7. Gender equality & $\begin{array}{l}\text { Global Gender Gap Report suggests that at the current rate of change it would take another } 118 \text { years to close the economic } \\
\text { gender gap. Gender equality also means access to health, education, and political power and is fundamental to fair societies. }\end{array}$ \\
\hline 8. Global trade and investment & $\begin{array}{l}\text { International trade and investment needs to adapt to changing powers of influence, particularly with disruptions to } \\
\text { traditional trading blocs. Regulatory frameworks need to adapt alongside these changes to ensure fair and equitable trade. }\end{array}$ \\
\hline 9. Long term investment & $\begin{array}{l}\text { Stability is achieved through long-term economic growth through investment in infrastructure, properly maintaining what } \\
\text { exists, and supporting social wellbeing. The global financial crisis has encouraged short-term investment for short-term } \\
\text { gains. }\end{array}$ \\
\hline 10. Healthcare systems & $\begin{array}{l}\text { Due to medical advancements people are generally living longer, healthier lives. Challenges remain with regards to } \\
\text { responding to pandemics, coping with aging populations, dealing with diseases of lifestyle, and the prohibitive costs } \\
\text { associated with equal access to healthcare. }\end{array}$ \\
\hline
\end{tabular}


Table 3. Examples of empirical work addressing Moray's seven problems of the future.

\begin{tabular}{|c|c|c|}
\hline Challenge & Examples & Comments \\
\hline Water issues & $\begin{array}{l}\text { Alli et al. (2013); Fang \& Sun, 2016; } \\
\text { Kalantzis et al. (2016); Sauer \& Rüttinger } \\
\text { (2004) }\end{array}$ & $\begin{array}{l}\text { A small number of ergonomics } \\
\text { studies in this challenge area }\end{array}$ \\
\hline Food issues & -- & $\begin{array}{l}\text { While there is plenty of work on } \\
\text { the ergonomics of agriculture, } \\
\text { this work is not linked directly to } \\
\text { sustainable food production }\end{array}$ \\
\hline Energy issues & $\begin{array}{l}\text { Beltman et al. (2013); Christina et al. } \\
\text { (2014); Cocron et al. (2013); Fréjus \& } \\
\text { Guibourdenche (2012); Hilliard \& } \\
\text { Jamieson (2011); Hilliard et al. (2016); } \\
\text { Katzeff et al., (2012); Kobus et al. (2013); } \\
\text { Revell \& Stanton (2016); Sauer et al. } \\
\text { (2004); Sauer \& Rüttinger (2004); } \\
\text { Stedmon et al. (2013) }\end{array}$ & $\begin{array}{l}\text { The widest range of ergonomics } \\
\text { work has been completed in this } \\
\text { challenge area }\end{array}$ \\
\hline Urbanisation & $\begin{array}{l}\text { de Carvalho (2012); Guimarães (2012); } \\
\text { Steffan (2012); Wolf (2003) }\end{array}$ & $\begin{array}{l}\text { A small number of ergonomics } \\
\text { studies in this challenge area but } \\
\text { the work is only theoretical and } \\
\text { mostly at the } 2012 \text { IEA Congress }\end{array}$ \\
\hline $\begin{array}{l}\text { Violence \& } \\
\text { terrorism }\end{array}$ & $\begin{array}{l}\text { Fiore et al. (2003); Hancock \& Hart } \\
\text { (2002); Koller et al. (2009); Mayhorn et } \\
\text { al. (2004); Nickerson (2011); Saikayasit } \\
\text { et al. (2013); Wise (2002) }\end{array}$ & $\begin{array}{l}\text { An initial spike at HFES meetings } \\
\text { post-9/11; followed by empirical } \\
\text { work on a range of technology- } \\
\text { based solutions }\end{array}$ \\
\hline $\begin{array}{l}\text { Pollution \& } \\
\text { waste }\end{array}$ & $\begin{array}{l}\text { Durugbo (2013); Cirjaliu, \& Draghici } \\
\text { (2016); Engkvist (2010); Genaidy et al. } \\
\text { (2009); Hanson \& Vangeel (2014); } \\
\text { Koukoulaki (2014) }\end{array}$ & $\begin{array}{l}\text { Relatively little ergonomics work } \\
\text { in this area; mostly in the } \\
\text { ergonomics of recycling centres } \\
\text { and reduction of waste through } \\
\text { lean manufacturing }\end{array}$ \\
\hline $\begin{array}{l}\text { Health \& } \\
\text { medicine }\end{array}$ & Carayon (2011) & $\begin{array}{l}\text { This book looked at health } \\
\text { ergonomics in general but did } \\
\text { not look at issues with regards to } \\
\text { the efficient running of whole } \\
\text { healthcare systems }\end{array}$ \\
\hline
\end{tabular}


Table 4. Significant milestones in ergonomics' response to Moray's challenges

\begin{tabular}{|c|c|}
\hline Year & Where \\
\hline 1992 & $\begin{array}{l}\text { Nickerson (1992) at HFES Annual } \\
\text { Meeting }\end{array}$ \\
\hline 1995 & $\begin{array}{l}\text { Moray (1995) in Ergonomics and } \\
\text { Nickerson \& Moray (1995) book } \\
\text { chapter }\end{array}$ \\
\hline 1996 & $\begin{array}{l}\text { Garcia-Acosta (1996), Masters' } \\
\text { thesis }\end{array}$ \\
\hline 1997 & $\begin{array}{l}4^{\text {th }} \text { Ergonomics Congress of Latin } \\
\text { America }\end{array}$ \\
\hline 1998 & $\begin{array}{l}\text { Charytonowicz (1998), ODAM } \\
\text { conference paper } \\
\text { Vicente (1998) in Systems } \\
\text { Engineering }\end{array}$ \\
\hline 1999 & $\begin{array}{l}\text { Meister (1999) in The history of } \\
\text { human factors and ergonomics }\end{array}$ \\
\hline 2000 & Shahnavaz (2000) in Ergonomics \\
\hline 2006 & Steimle \& Zink (2006) book chapter \\
\hline 2007 & $\begin{array}{l}\text { Brown (2007) New Zealand } \\
\text { Ergonomics Society Conference } \\
\text { Manuaba (2007) in Journal of } \\
\text { Human Ergology }\end{array}$ \\
\hline 2008 & $\begin{array}{l}\text { Hedge (2008) in HFES Bulletin } \\
\text { Thatcher (2008) in Cyberg '08 } \\
\text { conference }\end{array}$ \\
\hline
\end{tabular}

Guimarães \& Soares (2008) in Ergonomics

2009 Scott (2009) in Ergonomics in developing regions: needs and applications

2010 Hanson (2010) in her IEHF keynote address

2012 Garcia-Acosta et al. (2012) in Theoretical Issues in Ergonomics Science

2013 Haslam \& Waterson (2013) in Ergonomics

Thatcher (2013) in Ergonomics Zink \& Fischer (2013) in Ergonomics

\section{Relevant milestones}

Role of ergonomics for environmental management

Role of ergonomics in dealing with impending world crises, especially environmental concerns

Defining ergoecology (in Spanish)

Conference theme was Eco-ergonomics (ecoergonomia in Spanish)

The term eco-ergonomics is first used in English

Proposed a systems approach for ergonomics to solve global problems

Gives a critical reflection on the global

development of ergonomics

Refers to the triple bottom line of sustainability for technology transfer

Definition of human factors and sustainable development

The term eco-ergonomics emerges again

Proposed a systemic, holistic, interdisciplinary and participatory (SHIP) approach to sustainability

First use of "green ergonomics"

Used the term "ecological ergonomics"

Klaus Zink forms the Human Factors and

Sustainable Development Technical Committee (HFSD TC) of the IEA

Considers Moray's future in the context of developed vs. developing countries

Provided a collection of ergonomics studies in a wide variety of low- and middle income contexts, demonstrating global applications Uses the term "green ergonomics"

Ergoecology defined for English-speaking countries

Special Issue on ergonomics and sustainability

Green ergonomics defined

Sustainable development and human factors explained

Margaret Hanson forms the Green Ergonomics SIG of the CIEHF

Two Special Issues on human factors and climate change

Green ergonomics and ergoecology compared and values for the future of ergonomics introduced

Sustainable system-of-systems approach introduced

Special Issue on ergonomics and sustainability 
Table 5. Selected trends and projected developments for social, economic, and environmental indicators

\begin{tabular}{|c|c|c|}
\hline Theme & Trend & $\begin{array}{l}\text { Projected developments } \\
\text { towards } 2050\end{array}$ \\
\hline Population growth & $\begin{array}{l}\text { World population currently } 7.5 \\
\text { billion and growing at } 1.11 \% \\
\text { per annum; annual population } \\
\text { growth is slowing } 1\end{array}$ & $\begin{array}{l}\text { Projected to be }+9.7 \text { billion people by } \\
2050 \text { with growth rate slowing to less } \\
\text { than } 0.5 \% \text { per annum }{ }^{1}\end{array}$ \\
\hline $\begin{array}{l}\text { Agriculture, food } \\
\text { and water }\end{array}$ & $\begin{array}{l}<6 \mathrm{~m}^{3} \text { fresh water per capita, } \\
\text { down from }>13 \mathrm{~m}^{3} \text { per capita in } \\
1962^{2} \\
\text { World population currently } \\
\text { requires } 2287 \text { million tonnes } \\
\text { of cereals }\end{array}$ & $\begin{array}{l}\text { Projected World population will require } \\
3012 \text { million tonnes of cereals by } 2050 \text { if } \\
\text { not used for biofuels }\end{array}$ \\
\hline $\begin{array}{l}\text { Biodiversity and } \\
\text { the natural world }\end{array}$ & $\begin{array}{l}\text { Biodiversity loss } 1000 \text { to } \\
10000 \text { times higher than } \\
\text { "background" loss and appears } \\
\text { to be accelerating } 5\end{array}$ & $\begin{array}{l}\text { Projected to have lost } 10 \% \text { of current } \\
\text { biodiversity by } 2050^{5}\end{array}$ \\
\hline Climate change & $\begin{array}{l}\mathrm{CO}^{2} \text { equivalents currently } \\
+407 \mathrm{ppm} \text { and growing at } \\
2.11 \mathrm{ppm} \text { per annum with the } \\
\text { rate is increasing6 }\end{array}$ & $\begin{array}{l}\mathrm{CO}^{2} \text { projections largely based on ocean } \\
\text { absorption models and human } \\
\text { interventions. } \mathrm{CO}^{2} \text { will reach }+685 \mathrm{ppm} \\
\text { without significant action by } 2050 \text {, } \\
\text { equating to }+3^{\circ} \mathrm{C} \text { by } 2050^{6}\end{array}$ \\
\hline $\begin{array}{l}\text { Economics and } \\
\text { finance }\end{array}$ & $\begin{array}{l}21 \% \text { of population currently } \\
\text { live in poverty (less than } \\
\text { USD } 1.90 \text { per day) }^{7}\end{array}$ & $\begin{array}{l}12 \% \text { of population could live in poverty, } \\
\text { although this still equates to more than } 1 \\
\text { billion people }^{7}\end{array}$ \\
\hline Energy & $\begin{array}{l}\text { World energy consumption in } \\
2015 \text { was }+13000 \text { million } \\
\text { tonnes of oil equivalent }{ }^{8}\end{array}$ & $\begin{array}{l}\text { Projected to be }+16000 \text { million tonnes of } \\
\text { oil equivalent with sources moving from } \\
\text { oil and coal to natural gas and } \\
\text { renewables }^{8}\end{array}$ \\
\hline $\begin{array}{l}\text { Health and } \\
\text { education }\end{array}$ & $\begin{array}{l}\text { World life expectancy at birth } \\
\text { in } 2015 \text { was } 71 \text { years } \\
91 \% \text { of children worldwide } \\
\text { enrolled in primary education } \\
\text { with strong gender bias } \\
\text { against females }^{10}\end{array}$ & $\begin{array}{l}\text { By } 2050 \text { life expectancy at birth is likely } \\
\text { to increase to at least } 73 \text { years } \\
\text { Sustainable Development Goals are to } \\
\text { have } 100 \% \text { enrolments by } 2015 \text {, but } \\
\text { current trends suggest stagnation in } \\
\text { Africa and Middle East } 10\end{array}$ \\
\hline $\begin{array}{l}\text { Politics and } \\
\text { security }\end{array}$ & $\begin{array}{l}\text { In } 2015,152000 \text { people were } \\
\text { killed in wars and conflict }{ }^{11}\end{array}$ & $\begin{array}{l}\text { It is virtually impossible to predict future } \\
\text { conflicts }\end{array}$ \\
\hline Society and cities & $\begin{array}{l}54 \% \text { urbanised in } 2014 \text { with } \\
\text { World rate increasing at about } \\
1.8 \% \text { per annum }{ }^{12}\end{array}$ & $\begin{array}{l}\text { Projected }+66 \% \text { world urbanisation by } \\
2050 \text { with greatest growth in Africa and } \\
\text { Asia }^{12}\end{array}$ \\
\hline \multicolumn{3}{|c|}{$\begin{array}{l}\text { 1. World Population Clock: http://www.worldometers.info/world-population/ } \\
\text { 2. Food and Agriculture Organization: http://data.worldbank.org/indicator/er.h2o.intr.pc } \\
\text { 3. Global Water Forum: http://www.globalwaterforum.org/ } \\
\text { 4. Food and Agriculture Organization: http://www.fao.org/docrep/014/i2280e/i2280e.pdf } \\
\text { 5. WWF Global: http://wwf.panda.org/about_our_earth/biodiversity/biodiversity/ } \\
\text { 6. https://www.co2.earth/ } \\
\text { 7. Food and Agriculture Organization: http://www.fao.org/docrep/014/i2280e/i2280e04.pdf } \\
\text { 8. World Energy Statistics: https://yearbook.enerdata.net/ } \\
\text { 9. World Health Organization: http://www.who.int/whr/1998/media_centre/50facts/en/ } \\
\text { 10. UNICEF: https://data.unicef.org/topic/education/primary-education/ } \\
\text { 11. World Health Organization: http://www.who.int/reproductivehealth/publications/en/ } \\
\text { 12. United Nations, Department of Economic and Social Affairs, Population Division (2015) }\end{array}$} \\
\hline
\end{tabular}


Table 6: Examples of themes from 'The world we made' (Porritt, 2013)

\begin{tabular}{|c|c|c|}
\hline \multirow[b]{2}{*}{ Theme } & \multicolumn{2}{|c|}{ State of the World in 2050} \\
\hline & Positive Developments & Negative Developments \\
\hline Agriculture, food and water & $\begin{array}{l}\text { Shift towards community-based living and affordable } \\
\text { (flat-pack) housing } \\
\text { Consumption of meat drops dramatically, whilst fish } \\
\text { consumption from sustainable fish sources increases } \\
\text { partly as the result of a revised EU Common Fisheries } \\
\text { Policy (adopted in 2018) }\end{array}$ & $\begin{array}{l}2017 \text { - } 1.7 \text { billion people in conditions of extreme water } \\
\text { stress which results in water riots in the Middle East } \\
2017 \text { - Peak oil production } \\
2025 \text { - Collapse of global food system leading to wide- } \\
\text { scale famine - the 'Great Famine' (climate change, } \\
\text { overpopulation, meant overconsumption, rising energy } \\
\text { prices) }\end{array}$ \\
\hline Biodiversity and the natural world & $\begin{array}{l}\text { Clear evidence of the link between some types of } \\
\text { insecticides (e.g., neonicotinoids) and species } \\
\text { extinction; additional funding secured across a range of } \\
\text { organisations (e.g., UNESCO,WWF) and NGOs to } \\
\text { provide restoration programmes to save reefs }\end{array}$ & $\begin{array}{l}\text { Loss of many species (deforestation and climate change) } \\
2020 \text { - more than } 135,000 \mathrm{~km}^{2} \text { of the world's reefs } \\
\text { either severely damaged or completely lost } \\
2021 \text { - Hurricane Wilma devastates the USA }\end{array}$ \\
\hline Climate change & $\begin{array}{l}2020 \text { - Houston Concord on Climate Change - first ever } \\
\text { comprehensive and binding agreement on greenhouse } \\
\text { gas emissions and drives to accelerate new forms of } \\
\text { renewable energy (e.g., geothermal power, wave and } \\
\text { tidal stream generated electricity) }\end{array}$ & $\begin{array}{l}2045 \text { - Worst years on record for climate change } \\
\text { disasters - hurricanes, droughts, wildfires }\end{array}$ \\
\hline Economics and finance & $\begin{array}{l}2015 \text { - Pro-Poor Urban Alliance Launched } \\
2018 \text { - World Bank report on wealth distribution } \\
\text { Formation of mutuals, cooperatives, credit unions and } \\
\text { wealthcare managers operating at a local level (largely } \\
\text { brought about by the demise of the private banking } \\
\text { industry) }\end{array}$ & $\begin{array}{l}\text { The legacy of the global financial crisis (2008) continues } \\
\text { well into successive decades. National public debt } \\
\text { continues until } 2026 \text { when a transformation of the } \\
\text { banking industry with laws enduring that public money } \\
\text { supply would be created by national banks (e.g., the UK } \\
\text { Bank of England, US Federal Reserve) }\end{array}$ \\
\hline Energy & $\begin{array}{l}2022 \text { - Kiev Treaty on Nuclear Decommissioning } \\
\text { Solar revolution and 'grid parity' (unit of electricity } \\
\text { from solar energy costs no more than unit of electricity } \\
\text { from other sources); boom in renewable energies }\end{array}$ & $\begin{array}{l}\text { Cyber-assaults and terrorist attacks on nuclear } \\
\text { installations partly lead towards the demise of nuclear } \\
\text { power } \\
2023 \text { - Oil and gas prices hit highest point }\end{array}$ \\
\hline Health and education & $\begin{array}{l}\text { Recognition that sugar consumption was too high, } \\
\text { moves to ban drinks and food stuffs that exceeded } \\
\text { stricter sugar levels. Similar moves in the USA and }\end{array}$ & $\begin{array}{l}2030-500 \text { million suffer from diabetes - earlier trends } \\
\text { on the increase such as obesity and type } 2 \text { diabetes now } \\
\text { a global problem impacting India, China, the Middle East }\end{array}$ \\
\hline
\end{tabular}




\section{State of the World in 2050}

\begin{tabular}{|c|c|c|}
\hline Theme & \begin{tabular}{|c|} 
Positive Developments \\
\end{tabular} & $\begin{array}{l}\text { Negative Developments } \\
\end{array}$ \\
\hline & $\begin{array}{l}\text { elsewhere to tax fatty foodstuffs; educational } \\
\text { programmes in schools and universities increasingly } \\
\text { focus on the local community }\end{array}$ & and elsewhere \\
\hline Politics and security & $\begin{array}{l}2018 \text { - World Bank publishes 'Wealth Distribution in } \\
\text { the } 21^{\text {st }} \text { Century' report } \\
\text { Improved cooperation between nations makes it } \\
\text { possible for monitor and carry out better surveillance } \\
\text { on potential terrorists }\end{array}$ & $\begin{array}{l}\text { Cyberattacks on nuclear plants and national } \\
\text { infrastructure } \\
\text { Increasing disparity between the rich and the poor ( } 2016 \\
\text { - richest 1\% of the world's population own 50\% of } \\
\text { global assets, this figure continues to rise) } \\
\text { Youth and graduate unemployment grows } \\
2023-2038 \text { The War of the Ages }\end{array}$ \\
\hline Society and cities & $\begin{array}{l}2021 \text { - Lhasa declaration commits all world faiths to a } \\
\text { series of targets around environmental issues, poverty } \\
\text { reduction and active engagement in the community } \\
2041 \text { - Reconciliation between China and Tibet } \\
\text { 'Eco-cities' where water, energy and ICT systems are } \\
\text { bundled together to coordinate and minimise } \\
\text { environmental damage }\end{array}$ & $\begin{array}{l}2020 \text { - World population predicted to peak at } 8.6 \text { billion } \\
\text { in } 2050 \text {, but to drop to } 8.3 \text { billion in } 2100 \\
2035 \text { - Final evacuation of New Orleans } \\
2050 \text { - increase (relative to } 2015 \text { ) in the extent of } \\
\text { poverty in urban environments ( } 2.7 \text { billion) }\end{array}$ \\
\hline Technology and manufacturing & $\begin{array}{l}2020 \text { - Continuing rise in computing power - } \\
\text { continuation of the upwards trajectory of Moore's Law } \\
2031 \text { - European SuperGrid completed; technologies } \\
\text { such as 3D printing lead to a resurgence in the } \\
\text { manufacturing sector }\end{array}$ & $\begin{array}{l}2019 \text { - Cyber-terrorist attacks on nuclear reactors in the } \\
\text { USA and UK } \\
2021-2030 \text { - The Internet Wars - set up by legal and } \\
\text { illegal organisations of shadow internet systems and } \\
\text { networks to restrain the power of corporations and } \\
\text { governments }\end{array}$ \\
\hline Travel and transport & $\begin{array}{l}2018 \text { - tariffs on biofuels phased out } \\
2020 \text { s - acceleration in development of air-capture } \\
\text { (technologies which recycle } \text { CO }^{2} \text { ) } \\
2025 \text { - First commercial flights with } 100 \% \text { biofuels } \\
2028 \text { - Launch of C } 2050 \text { Airliner } \\
\text { Improvements in the design of batteries lead to a step } \\
\text { forward in the use of electric vehicles }\end{array}$ & $\begin{array}{l}2050 \text { - Aviation still biggest user of fossil fuels, but } \\
\text { reductions in place caused by use of biofuels and } \\
\text { advances in air-traffic control systems } \\
2050 \text { - Freight carried by ships still very large, but } \\
\text { reduced as compared to } 2010 \text { ( } 8.4 \text { billion tonnes as } \\
\text { compared to } 7.9 \text { billion in } 2050)\end{array}$ \\
\hline
\end{tabular}


Figure 1. Projected global population growth through to 2050 [Source: US Census Bureau, International database, August 2016 update]

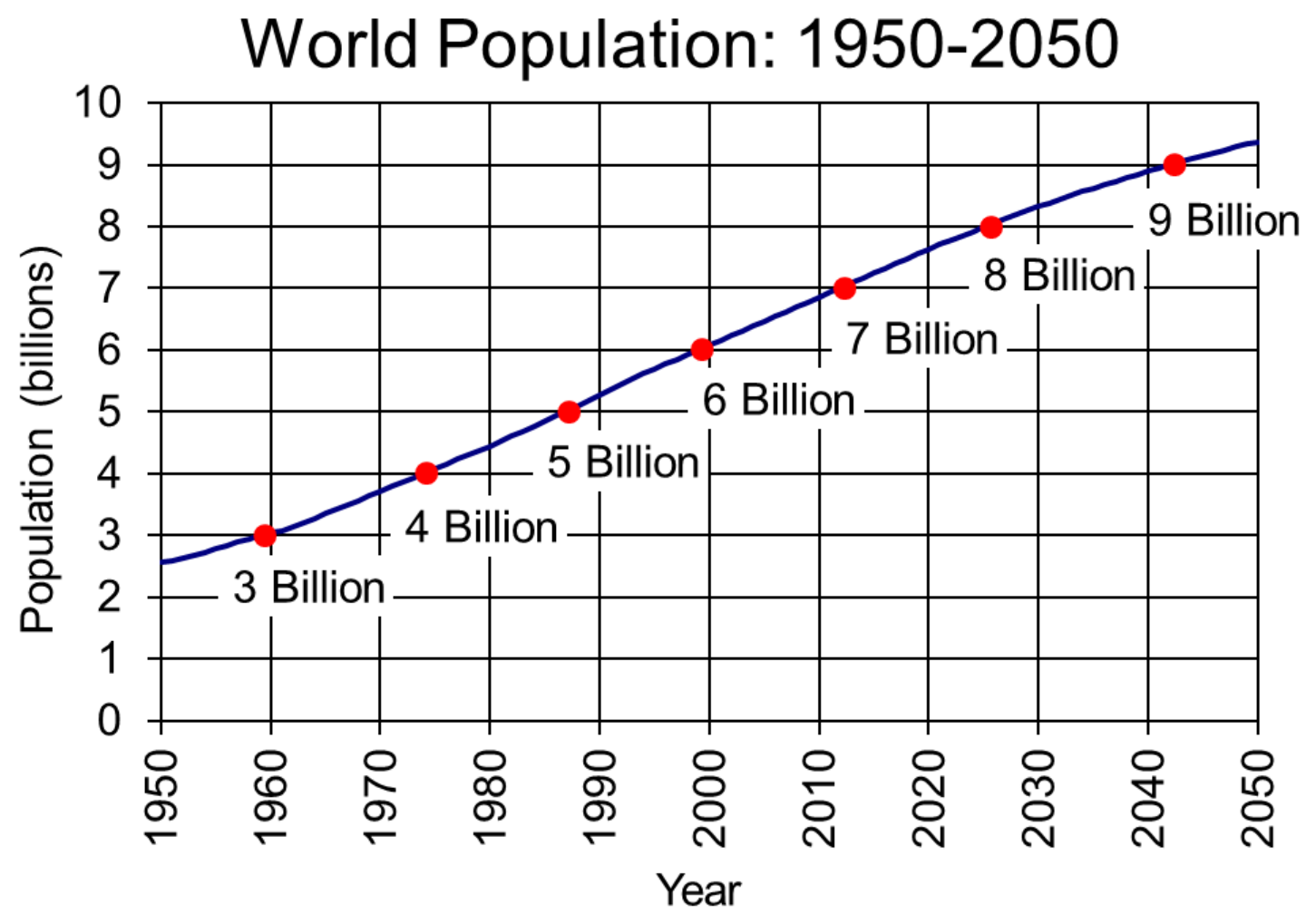

